Nowoczesne Systemy Zarządzania

Zeszyt 12 (2017), nr 1 (styczeń-marzec)

ISSN 1896-9380, s. 71-88

Modern Management Systems

Volume 12 (2017), No. 1 (January-March)

ISSN 1896-9380, pp. 71-88
Instytut Organizacji i Zarządzania

Wydział Cybernetyki

Wojskowa Akademia Techniczna

w Warszawie

Institute of Organization and Management

Faculty of Cybernetics

Military University of Technology

\title{
Partnership organizational mechanism in rural areas development: stakeholders analysis
}

\section{Partnerski mechanizm organizacyjny w rozwoju obszarów wiejskich: analiza interesariuszy}

\author{
Vilma Atkočiūniene̊ \\ Aleksandras Stulginskis University \\ Faculty of Economics and Management \\ Business and Rural Development Management Institute \\ e-mail:vilma.atkociuniene@gmail.com \\ Eglẻ Štareikẻ \\ Aleksandras Stulginskis University \\ Faculty of Economics and Management \\ Business and Rural Development Management Institute \\ e-mail: egle.stareike@gmail.com
}

\begin{abstract}
Process of rural areas development becoming more open and complex. Impact of stakeholders is getting more clear and transparent for decisions and acts which are done in rural areas. Success and effectiveness of development initiatives ensuring stakeholder's goals that need to be linked with development purposes of rural organizations, which are implemented acting in partnership. Partnership organizational mechanism synchronizes actions and interactions of stakeholders and other elements of the mechanism, organizational changes and also combines interests of stakeholders and motivates them to engage and participate in rural development initiatives in order to solve existing problems. The purpose of this article - to define partnership organizational mechanism and determine stakeholders related with mechanism's functioning. During the investigation the evolution of the mechanism concept was analyzed, that created preconditions for creation of concept of partnership organizational mechanism in rural areas development. The missions analysis of Lithuania's 51 local action groups development strategies (2007-2013 year) allowed to identify stakeholders, that are related to partnership organizational mechanism functioning in rural areas development.
\end{abstract}

Keywords: partnership, organization, mechanism, stakeholders 
Abstrakt: Proces rozwoju obszarów wiejskich staje się bardziej otwarty i złożony. Wpływ zainteresowanych stron jest coraz wyraźniejszy i przejrzysty w przypadku decyzji i działań podejmowanych na obszarach wiejskich. Sukces i skuteczność inicjatyw rozwojowych zapewniających cele interesariuszy, które muszą być powiązane z celami rozwojowymi organizacji wiejskich, są realizowane w partnerstwie. Mechanizm organizacyjny partnerstwa synchronizuje działania i interakcje interesariuszy oraz innych elementów mechanizmu, zmiany organizacyjne, a także łączy interesy zainteresowanych stron i motywuje ich do angażowania się, jak również uczestnictwa w inicjatywach rozwoju obszarów wiejskich w celu rozwiązania istniejących problemów. Cel tego artykułu to zdefiniowanie mechanizmu organizacyjnego partnerstwa i określenie interesariuszy związanych z funkcjonowaniem tego mechanizmu. W trakcie badania przeanalizowano ewolucję koncepcji mechanizmu, która stworzyła wstępne warunki dla koncepcji partnerstwa mechanizmu organizacyjnego w rozwoju obszarów wiejskich. Analiza misji 51 strategii rozwoju lokalnych grup działania Litwy (lata 2007-2013) pozwoliła zidentyfikować interesariuszy, którzy związani są z funkcjonowaniem mechanizmu organizacyjnego partnerstwa w rozwoju obszarów wiejskich.

Słowa kluczowe: partnerstwo, organizacja, mechanizm, interesariusze

\section{Introduction}

Rural areas are less homogeneity, so both rural areas and their populations become subjects of large rural developments, tension and various often conflicting evolutionary processes. Process of rural area development becoming more open, complex, depending on the various stakeholders: local residents, local authorities, local action groups, private businesses, various associations, visitors of rural areas and decisions or actions of other actors. It is clearly perceptible stakeholder's impact, especially those in rural areas, which were broken up by differently motivated and interested actors. Rural and suburban areas remained more natural, became more productive, but they have also become a fighting instrument for agricultural structures, landscaping, infrastructure, public and private management. In many countries stakeholders' action in partnership while managing rural areas resources is a recognized element being important both in policy formulation and in the planning and implementation of activities. Stakeholders interested in rural development process are obliged to understand national and international change management rules reaching optimal results to act in partnership, therefore a special attention have to be paid to examine territorial change management mechanisms, ways and means. The purpose of the research - to define partnership organizational mechanism and determine stakeholders related with mechanism's functioning.

\section{Research objectives:}

1) determine factors affecting complexity of the rural areas development;

2) identify the main elements and processes of partnership organizational mechanism;

3) reveal stakeholders and their interests of Lithuanian rural areas development.

\section{Research methodology}

The scientific literature by E. Ostrom $(2000,2005)$, P. Machamer, et al. (2000), L. Hurwicz (2007), K. Pajunen (2008), E. Rybakovas (2009), P. Zakarevičius (Zakarevičius, 2010, pp. 123-132), B. Dalal-Clayton, S. Bass (2012), M. Milkowski (2014) 
and others were studied applying the following methods: logical, abstraction, comparison, content analysis, collation. While using conceptual units frequency of keyword usage was counted, various text elements connections between one another and whole scope of information were investigated. While using comparison method it was identified partnership organization mechanism elements, their expression, relations between them, fulfillment of partnership organizational mechanism aim in respect of stakeholder's interests. Defined the concept of "partnership organizational mechanism". Making research has led to the assumption that stakeholders interest-based organization is local action group (LAG). LAG includes private, public and non-governmental sectors, represents various interests of the people living in the LAG territory, which can be equated to the partnership organizational mechanism, which purpose of functioning is rural development.

\section{Complexity of management of rural areas development}

A number of various reasons exist which trigger problems in management of development of rural areas. First, the problems are related to complexity of development of rural residential areas: comparative homogeneity of agriculture and farming generates new opportunities for the expression of stakeholders (service providers, new settlers, tourists, visitors, etc.). Then the necessity to coordinate needs and interests of stakeholders arises. The second reason is ever increasing involvement of population manifesting through desire to participate in decision making processes and local projects, through different lobby groups, various formal and informal associations, etc. The third problem results from different management levels: local, regional and national levels are inextricably interconnected, where not only decisions made at these levels, but also decisions made at the European level and regulations must also be consistent and generate synergistic effects. Fourth, globalization has been engaged in relation to rural development, in both the developed and developing worlds. In some instances, studies have shown globalization to have opened up new opportunities for local based rural development projects that exploit new niche markets or the search for cheap labour (Bebbington, Batterbury, 2001; Darkoh, Mbaiwa, 2002; Pérez Sáinz, Andrade-Eekhoff, 2003). In other contexts, globalization has been identified with disinvestment and the marginalization of rural economies (Epp, Whitson, 2001; Gray, Lawrence, 2001). Globalization has both positive and negative impacts on rural development, accelerating growth in many rural regions of the developing world, but also creating real dangers that the rural poor will be left behind by lack of skills, capital and access to resources (Killick, 2001, Woods, 2007, pp. 485-507).

In humanities, institutional economics, political science, sociology and management discourse development of rural areas is an interdisciplinary phenomenon, which 
covers several topics: long-term experience and public actions, common interests, collective management, ownership rights, management and development of communities, public governance and equal opportunities to access resources (Torre, Zuindeau, 2009, pp. 1-24), etc. Various stakeholders with different needs in the decision making process are included or involve themselves in the management process. They set up coordination centres including such processes as interaction, collective actions, enabling and learning, by paying particular attention to participation and consulting.

Rather diverse presentations of the concept of public governance are found in scholar literature. M. Pasquier, J. P. Villeneuve (M. Pasquier, J. P. Villeneuve, 2007 pp. 147-162) define governance as rules and models, enabling public actions to happen in increasingly differentiated (and autonomous) society with the increasing number of players. The concept of governance may also be defined as actions of government in accepting compromises or as a multilevel and multipolar coordination process in asymmetric context, with many solution centres.

With the introduction of a significant number of institutional innovations resulting from decentralization and contracting processes in many countries, stakeholders have been encouraged to try new forms of public governance and become involved in decision making processes, originating from hierarchical governance structures to public institutions from network type organizations (Kooiman, 2000; Powel, 1991), which interconnect partnership of public and private sector (Wettenhal, 2003), includes very diverse groups of stakeholders (Pierre, 2000) and most of territorial levels (Hooghe, Marks, 2001).

Sector partnership is considered as most important victory of public governance. Public and private sector partnership is understood as diverse cooperation of public and private organizations in providing better quality public services, developing various forms of partnerships in order to involve and engage various stakeholders groups. The components of such partnerships could be identified as: obligations of both sectors; joint programs, projects or strategies, efforts to efficient performance; harmonization of stakeholders' actions; share of responsibility for possible problems; addressing threats (e.g. unreliability of partners) et al. (Yestcombe, 2007; Raipa et al., 2016). According to A. Raipa and others (2012) partnership can be utilized as an effective tool and more rational form of governance in order to achieve specific objectives.

Implementation of public policy is multidimensional and encompasses many diverse subjects and realization of their collective interests; therefore area management becomes oriented towards achievement of specific local, regional or national development objectives:

- To create favourable conditions for implementation of territorial development projects;

- To contribute to introduction of wide-scale consulting systems;

- To facilitate involvement of stakeholders and encourage their participation; 
- To make a decision concerning the trajectory of locality development;

- To restrict stakeholders of a certain profile from accessing the area;

- To avoid direct confrontations between interests parties, economic activities and localities;

- Other.

The definition of area management derives from the importance of area management standards and administrative areas alongside participation of stakeholders, involved in the process of collective decision making and economic development. Solving of rural area management (Welch, 2002, pp. 443-459) and development sustainability (Lowe, Ward, 2007, pp. 307-317) problems in areas as well as multi-level management and inter-territorial coordination issues have been becoming increasingly relevant. This leads to solution of problems of management of rural areas, application of solution methods in areas, multi-level management and coordination between areas. Area management consists of development of collective projects, fostering local/global relations and coordination on actions in directing changes towards sustainability (Rey-Valette, 2008).

Management tools are designed for facilitating participation of stakeholders by coordinating their varied interests (for example, of society representatives and private lobby organizations; politicians and members of various associations, etc.) in the decision making process, which has been increasingly becoming fragmentary and dispersed and increasingly less secured.

\section{Partnership organizational mechanism}

For the purposes of analysis of the concept of organizational mechanism it should be noted that the concept of mechanism is not new to the social studies: initially, the term "mechanism" appeared in the research based on methodological individualism (Elster, 1989; Stinchcombe, 1991, pp. 367-388), as well as in the research of scientific realism (Harre, 1985; Little, 1991) and critical realism (Bhaskar 1978; Reed, 2001). However, in the past years the concept of mechanism is being used in a number of different scientific researches seeking to explain organizational changes (Table 1), to show systemic change of expression or process, movements and interactions, as well as to make more efficient organizational process. In practice it is often found concepts like: market mechanism, pricing mechanism, financial mechanism, management mechanism, organizational mechanism. 


\begin{tabular}{|c|c|c|}
\hline Concept of the mechanism & Year & Researcher \\
\hline $\begin{array}{l}\text { Market mechanism is a process, primary regulator, covering actions of market participants, as a consequence of } \\
\text { which a new market balance as well as new demand, supply and price originate. Price mechanism shall inevitably } \\
\text { create balance in each market, and this also means the overall balance in the whole economy. }\end{array}$ & 1963 & J. A. Schumpeter \\
\hline $\begin{array}{l}\text { Information processing method (in cognitive psychology) means that perception and learning can be analysed } \\
\text { through a number of stages, during which certain components (mechanisms) perform a series of transformation } \\
\text { or recording of certain information. }\end{array}$ & 1975 & G. H. Bower \\
\hline Explanation on how components of a certain theory interact with each other. & 1989 & J. Elster \\
\hline $\begin{array}{l}\text { Transfer process during which information travels in space and time from one point to another } \\
\text { (between individuals). }\end{array}$ & 1987 & H. J. Krone \\
\hline $\begin{array}{c}\text { Fragments of theory on subjects (e.g., individuals) of different levels, in comparison with fundamental subjects of } \\
\text { theories (e.g., groups), which aim to make the theory of a higher level more adaptable, clear and of more general } \\
\text { nature. }\end{array}$ & 1991 & A. L. Stinchcombe \\
\hline $\begin{array}{l}\text { This is a device of movably connected bodies dedicated to achieving a movement of a certain nature. The transfer } \\
\text { of movement is an essential nature of mechanism. Mechanism always contains one or several initial (incoming, } \\
\text { driving), intermediate and final (exit, driving) units. }\end{array}$ & 1990 & S. Naujokaitis \\
\hline Explanation on what actions took place and what were the causes for these actions. & 1998 & Hernes \\
\hline $\begin{array}{l}\text { Social mechanism is a credible hypothesis, or a set of them, which can serve as reliable assumptions, explanation } \\
\text { of certain social phenomena and explanation of interactions between individuals or individuals and social entirety. }\end{array}$ & 1998 & T. Schelling \\
\hline $\begin{array}{l}\text { Four fundamental principles may be characteristic to social mechanism: action, precision, abstraction } \\
\text { and conversion. }\end{array}$ & 1998 & P. Hedstrom, R. Swedberg \\
\hline Action organized in such a way as to continuously cause recurrence of the beginning and end. & 2000 & $\begin{array}{l}\text { P. Machamer, L. Darden, } \\
\text { C. F. Craver }\end{array}$ \\
\hline Mechanisms are processes, which explain causation between the variables. & 2002 & J. L. Campbell \\
\hline $\begin{array}{c}\text { A mechanism for behavior is a complex system, where the interactions between parts can be characterized by } \\
\text { direct, invariant, change-relating generalization. }\end{array}$ & 2002 & S. Glennan \\
\hline
\end{tabular}




\begin{tabular}{|c|c|c|}
\hline $\begin{array}{l}\text { Collective actions (social movements, organizational solutions, dispersion of ideas in society, etc.), consisting of } \\
\text { individual-collective relations. Mechanisms enable explanation on how separate individuals can achieve } \\
\text { collective actions. }\end{array}$ & 2004 & G. F. Davis \\
\hline $\begin{array}{l}\text { A mechanism is characterized as a structure performing a function in virtue of its component parts, component } \\
\text { operations, and their organization }\end{array}$ & 2005 & $\begin{array}{l}\text { W. Bechtel, } \\
\text { A. Abrahamsen }\end{array}$ \\
\hline $\begin{array}{l}\text { Process consisting of source of information transfer, information contents, intermediary of information transfer } \\
\text { having an impact on efficiency and effectiveness of information transfer, recipient of information and feedback. }\end{array}$ & 2005 & B. Sindhav, P. T. Adidam \\
\hline $\begin{array}{l}\text { Provision of public services is related to multiple interactions of dependent factors, and public policy making is } \\
\text { related to multiple processes. In case of this complex activity and interaction of diverse factors and players } \\
\text { networks develop wherein public governance mechanisms - mutual trust and agreement - are identified. }\end{array}$ & 2006 & S. P. Osborne \\
\hline $\begin{array}{l}\text { Communication system, participants of which interchange messages with each other, and all these messages } \\
\text { determine a certain result. Mechanism is like a machine, accumulating and processing messages it receives } \\
\text { and thus concentrates personal information provided by most players (true or false). }\end{array}$ & 2007 & L. Hurwicz \\
\hline Social innovations, able to make influence on social change and operating as a mechanism. & 2008 & $\begin{array}{l}\text { J. A. Phills, K. Deiglme- } \\
\text { ier, D.T. Miller }\end{array}$ \\
\hline $\begin{array}{l}\text { Organizational mechanism can be understood as creation of organizational culture (field of relationships), } \\
\text { its realization and nurturing. }\end{array}$ & 2010 & $\begin{array}{l}\text { L. Šimanskienè, } \\
\text { T. Tarasevičius }\end{array}$ \\
\hline $\begin{array}{l}\text { Functions performed by organizational processes, which are the expression of objective achievement, } \\
\text { and practical implementation. Organizational mechanism forms a chain: objective - function - process - result. }\end{array}$ & 2010 & P. Zakarevičius \\
\hline $\begin{array}{l}\text { An organizational mechanism is a means of coordination of the organization's activities providing information to } \\
\text { the stakeholders, who persuade the public to act in a certain way or cause change in the environment. }\end{array}$ & 2011 & $\begin{array}{l}\text { S. Esparcia R. Centeno, } \\
\text { R. Hermoso, E. Argente }\end{array}$ \\
\hline $\begin{array}{l}\text { Method, providing coordination within organization, concentrating additional information for pro-active } \\
\text { stakeholders, who persuade society to behave in a certain way or cause environmental changes. }\end{array}$ & 2012 & F. C. Lunenburg \\
\hline $\begin{array}{l}\text { "Institutional mechanisms", when behaviour of social system and its components is determined by institutional } \\
\text { objects, i.e. norms or conventions. }\end{array}$ & 2013 & C. Hédoin \\
\hline $\begin{array}{l}\text { These are organized systems, involving causally linked constituents and operations (or actions). Constituents of } \\
\text { mechanism interact with each other together contributing to increasing operational capacity of mechanism. }\end{array}$ & 2014 & M. Milkowski \\
\hline
\end{tabular}

Source: own elaboration based on Schumpeter, 1963; Bower, 1975; Elster, 1989; Krone, Jablin, Putnam, 1987; Stinchcombe, 1991; Naujokaitis, 1990; Hernes, 1998; Schelling, 1998; Hedstrom \& Swedberg, 1998; Machamer et al., 2000; Campbell, 2001; Glennan, 2002; Davis, 2004; Bechtel \& Abrahamsen, 2005; Sindhav \& Adidam, 2005; Osborne, 2006; Hurwicz, 2007; Phills, K. Deiglmeier et al., 2008; Šimanskienė \& Tarasevičius, 2010; Zakarevičius, 2010; Esparcia et al., 2011; Lunenburg, 2012; Hédoin, 2013 ; Milkowski, 2014. 
The theory of mechanics (Naujokaitis, 1990) proposes that mechanism consists of units which are interconnected in certain connecting (kinematic) pairs. Mechanism units are defined as solid bodies or an entirety of firmly connected bodies. Mechanisms can be spatial (when units move in space, their movement can be divided into three axes and described by six coordinates), and flat (when units of mechanism move on one plane or parallel planes, then three coordinates are sufficient for describing their movement). When performing structural analysis of mechanism it is necessary to know how to identify passive units of mechanism and surplus kinematic pairs (so called internal slackness of mechanisms). Passive units reinforce construction of mechanism and aid in transferring it through undefined positions, and surplus kinematic pairs replace one kind of friction with another kind of friction, increase coefficient of useful action, etc.

In mechanism design theory L. Hurwicz (2009) submits general methods for resource allocation mechanism analysis and improvement. The abovementioned theory plays a crucial role in most economic areas and in some political sciences; in most cases it has been successfully applied. During recent years scope of application of mechanism design theory has expanded as a consequence of the impact of globalization and intensive online trade, i.e. phenomena which impose new requirements on old institutions.

Hurwicz (Hurwicz, 1973, pp. 1-30) proposed methods which enable creating interaction rules (mechanisms) required for achieving the set system objectives. By applying mathematical methods L. Hurwicz disclosed that economic institutions can make decisions, interconnecting justice, individual rationality and social welfare. Mechanisms are required for achieving the set system objectives. Mechanism design provides formal mathematical and analytical measures, by application of which the issue on how to most effectively incite employees, tax payers or political leaders may be resolved.

The implementation of partnership principle has become a management tool for a wide range of policy areas, including areas from health to education or from preservation of area's resources to sustainable community development. The principle of partnership is no longer associated to city governance but is identified as important tool in rural areas development, allowing refocusing public projects of large scale into implementation small scale "bottom-up" initiative. As early as 1996 in Cork declaration also in currently updated and valid Cork declaration 2.0 it is highlighted that economic, social and environmental government and regional authority aims of rural policy have to reflect local needs and to be carried out implementing principle of partnership. Partnership becomes a tool helping to connect existing stakeholders' resources in order to achieve aims of specific area development. The partnership is defined as a targeted strategic relationship between independent stakeholders who share compatible objects, seek common benefit, recognizes a high degree of mutual independence. Stakeholders combine forces to achieve common 
goals, which are not easily reached while acting alone. Partnership is based on the competitive advantage of rural area development.

Definition of partnership allows distinguishing three important elements:

1. Partnership is a conscious action, because it is designed for a specific purpose;

2. Operation in partnership allows combining different resources of different stakeholders (e.g. financial, material resources, know-how etc.);

3. The pooling of resources and seeking for co-operation in partnership is based on competitive advantage of rural area development.

While creating a partnership it is important to bring together all stakeholders. Inability to attract some of the stakeholders can lead to weaknesses, limited possibility for actions and threats to achieving the desired results. When all relevant actors are together it is very important to firmly secure their participation which is possible while acting in partnership. Partnership becomes a tool for different nature stakeholders establishing connections, coordinating respective interests, sharing responsibility and cooperating in solving certain problems especially when informal partners are included (e.g. non-governmental organizations, community members). While seeking proper implementation stakeholders have to ensure common vision but also common strategy which they have to create via joint study of the issues involved. In this context, basic principles of long-term success can be identified (Table 2). These principles are not equal, because some of them are ideal for individual partners, while others - for collective (Lukesch, 2007). 
Table 2. The main principles of partnership

\begin{tabular}{|c|c|c|}
\hline Feature of success & \multicolumn{2}{|l|}{ Interpretation } \\
\hline Relatedness & $\begin{array}{l}\text { Each partner has strong ties to the territory or to certain aspects of } \\
\text { it. These ties can be emotional ones in respect to his/her origin; they } \\
\text { can be related to his/her specific activity (as an artist, tourist guide, } \\
\text { politician etc.); they can also be economic ties (ownership of land } \\
\text { or of a firm)... }\end{array}$ & \multirow{3}{*}{ 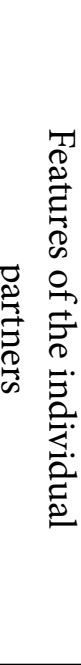 } \\
\hline Resonance & $\begin{array}{l}\text { The partners are good communicators and bridge-builders; they are } \\
\text { committed to cooperate with others, might they share their world } \\
\text { view or not. }\end{array}$ & \\
\hline Resource access & $\begin{array}{l}\text { The partners use their individual access to (human, financial, mate- } \\
\text { rial) resources to serve the common purpose: the bank manager pro- } \\
\text { vides support to financial issues; the school dean motivates students to } \\
\text { participate in accompanying research etc. They hold the keys to speci- } \\
\text { fic resources in hands: That's why they are called "key stakeholders".. }\end{array}$ & \\
\hline Representativeness & $\begin{array}{l}\text { As a group the partners constitute the "area in a nutshell". The part- } \\
\text { nership composition should be balanced in terms of gender, age, } \\
\text { profession, social status, political orientation, place of living, degree } \\
\text { of education etc. Ethnical, religious and other minorities or people } \\
\text { with specific needs should be also represented. }\end{array}$ & \multirow{3}{*}{ 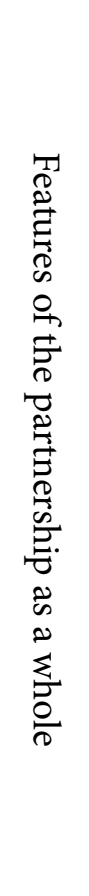 } \\
\hline Reciprocity & $\begin{array}{l}\text { The partnership is entitled and willing to set up equitable relation- } \\
\text { ships (economic exchange, knowledge and innovation, solidarity, po- } \\
\text { litical agreements etc.) with external partners, other regions, within } \\
\text { or across national boundaries, with trans-national organizations etc. }\end{array}$ & \\
\hline Recursiveness & $\begin{array}{l}\text { The partnership is related to embedded territorial entities (e.g. mu- } \\
\text { nicipalities) in a similar way as governance structures of larger ter- } \\
\text { ritorial entities are related to the local partnership. The partnership } \\
\text { is self-organised and sufficiently autonomous in its respective realm } \\
\text { of decision-making, and it does not interfere in the realm of deci- } \\
\text { sion-making of municipalities or other embedded entities. They are } \\
\text { supported and encouraged by the national/regional government in } \\
\text { the same way as they support and encourage the municipalities and } \\
\text { other local actors. }\end{array}$ & \\
\hline
\end{tabular}

Adopted from: R. Lukesch, 2007

The analyzed organizational mechanism of partnership consists of four main activities (Table 3):

1. Information activities are designed to introduce community members to possible partnership. This is transfer of information without seeking for feedback from informed person about possible involvement of informed person in community decision-making and self-realization techniques in rural areas.

2. Consulting activities - this is information supply, appeal to specialist for advice about community processes taking place in rural area. Consulting activities in rural areas are characterized by complexity and covers economic, 
financial, sociological, socio-psychological, psychodynamic, anthropological constructs. Also organizations development theories, political and practical aspects of the cultural - values, norms of behavior. Regardless of the mentioned qualities consultation as interference in rural areas development process will be ineffective. Therefore the result of consultation in rural areas is provision of professional information, advice or assistance in setting organizational goals and solving problems.

3. Engagement activities - helping for concerned to decide and become a partner in order to acquire the resources and capabilities of those who cannot provide them or exchange with those who need them in order to be able to participate fully in the economic, social and cultural life of rural areas. Most often engagement is characterized by a limited scope of time in order to start operating as soon as possible, therefore stakeholders are usually included within the network structure or functioning regional / local organizations (e.g. LAG). Engagement of stakeholders as one of the components of partnership is because strategic leaders of rural areas know that authorities and social partners must be engaged.

4. Participation activities - the partnership includes a combination of mechanisms making rural areas development initiatives from the "top down" and "bottom- up". Effective participation in local communities may be problematic while involving private sector. Participation of all local community members is also limited. Engagement of Government / municipal / council members normally raises questions about their representation of rural areas. To PARTICIPATE means to be active in seeking community to rural area and carry out activities jointly with LAG as well as with social partners and community members.

Table 3. Activities of partnership organizational mechanism

\begin{tabular}{|c|c|c|c|}
\hline \multicolumn{4}{|c|}{ ACTIVITIES OF PARTNERSHIP ORGANIZATIONAL MECHANISM } \\
\hline Information & Consultation & Engagement & Participation \\
\hline $\begin{array}{l}\text { Information - } \\
\text { providing information } \\
\text { without feedback }\end{array}$ & $\begin{array}{l}\text { Consultation - } \\
\text { providing information } \\
\text { as feedback }\end{array}$ & $\begin{array}{l}\text { Engagement - } \\
\text { creation precondi- } \\
\text { tions to participate }\end{array}$ & $\begin{array}{l}\text { Participation - joint } \\
\text { work, joint decisions, } \\
\text { acting in partnership }\end{array}$ \\
\hline Measures of information & $\begin{array}{c}\text { Measures } \\
\text { of consultation }\end{array}$ & $\begin{array}{c}\text { Measures } \\
\text { of engagement }\end{array}$ & $\begin{array}{c}\text { Measures } \\
\text { of participation }\end{array}$ \\
\hline $\begin{array}{l}\text { Providing information } \\
\text { Information diversion } \\
\text { Induction } \\
\text { Knowledge transfer / } \\
\text { dissemination }\end{array}$ & $\begin{array}{c}\text { Providing opinion } \\
\text { Recommendation } \\
\text { Communication } \\
\text { Advice how to behave } \\
\text { Report of specialist or } \\
\text { expert }\end{array}$ & $\begin{array}{l}\text { Organization } \\
\text { Cooperation } \\
\text { Empowerment } \\
\text { Motivation } \\
\text { Connection of } \\
\text { resources }\end{array}$ & $\begin{array}{l}\text { Communication } \\
\text { Dialogue } \\
\text { Representation } \\
\text { Discussion } \\
\text { Negotiation } \\
\text { Consensus }\end{array}$ \\
\hline
\end{tabular}


Therefore, according to concepts and constituents of organizational mechanism and partnership, organizational mechanism is defined as simultaneous operation of organizational process elements (and their links), connected to each other, their interactions, comprising a group of interested individual and collective decisions and actions that lead to behavioral interactions and help to sustainable rural development. Partnership organizational mechanism - totality of information, consultation, engagement and participation decisions, also called nodes and their partnership actions connecting them into chains, while operating synchronously against each other.

\section{Stakeholders of partnership organizational mechanism}

P. Mahcamer et all (2006) emphasize that an exceptional feature of the partnership organizational mechanism is the stakeholders (subjects) comprising it, and their actions and behavior. The actions affect the change of environment, while the stakeholders perform certain roles in seeking the change of environment, i.e. a specific result. Otherwise speaking, the stakeholders with a specific aim seek results by performing respective functions and processes. According to K. Pajunen (Pajunen, 2008, pp. 1449-1468), depending on an partnership organizational mechanism, the spectre of the stakeholders can be rather wide - from a particular individual (head or owner of a company, a member of a community, etc.) to respective institutions (ministry, NGO, sector of rural social infrastructure, etc.). The stakeholders are individuals or groups, whose interests or actions are related to current problems, who are interested in a change, control the respective information and resources, and whose support is necessary in seeking to implement the changes (Aligica, 2006, pp. 79-90). S. Stoll-Kleemann and M. Welp (2006) define stakeholders as individuals or their groups, which are interested in certain activity and its results or the interests of which can be impacted by activities.

Any social system comprises two constituents: stakeholders and resources controlled by the stakeholders. Relationship between the system of the stakeholders and resources is realized through their control and interests. If the stakeholders are lacking resources to satisfy their interests, they try to create social connections (act in partnership) with other actors with available resources in order to satisfy their interests. Therefore, according to J. S. Coleman (2000), in the socio-economic system interests can be analysed only in combination with resources, which is a mandatory condition for existence of interests. According to E. Rybakovas (Rybakovas, 2009, pp. 15-27), seeking common objective of development may involve investment of different resources of the stakeholders: money, knowledge, time, social connections, labour force, material values, etc. 
It is important to correctly methodologically identify and analyse the stakeholders and their interests. According to the motives the stakeholders are driven by to maintain the connection with the partnership organizational mechanism, their objectives and gain they seek to obtain during cooperation, etc. They can be divided into primary (stakeholders, who are directly, both in a positive and negative way, influenced by the problematic issues, e. g.: farmers, residents of rural areas, children) and secondary (intermediaries of the processes taking place inside the organizational mechanism of development in the rural areas, e. g.: NGO, Government, etc.) (Dalal-Clayton, Bass, 2012).

Table 4. Stakeholders of the governance of Lithuanian rural areas development (research was carried out under missions of 51 Lithuanian rural local action groups for the period from 2007 to 2013)

\begin{tabular}{|c|c|c|c|}
\hline Target group & Stakeholders & $\begin{array}{l}\text { Number of local } \\
\text { action groups, which } \\
\text { missions provide } \\
\text { stakeholders }\end{array}$ & $\begin{array}{c}\text { Percent of } \\
\text { number of local } \\
\text { action groups, } \\
\text { which missions } \\
\text { provide stakeholders }\end{array}$ \\
\hline \multicolumn{4}{|c|}{ Primary stakeholder groups } \\
\hline \multirow{8}{*}{$\begin{array}{l}\text { Stakeholders, who } \\
\text { take problem- } \\
\text { solving measures } \\
\text { directed to other } \\
\text { stakeholders }\end{array}$} & Local community & 38 & $75 \%$ \\
\hline & $\begin{array}{l}\text { Residents of rural/ local/ } \\
\text { representative area }\end{array}$ & 24 & $47 \%$ \\
\hline & Other local organizations & 11 & $22 \%$ \\
\hline & People from rural area & 10 & $20 \%$ \\
\hline & NGO & 8 & $16 \%$ \\
\hline & Various social groups & 7 & $14 \%$ \\
\hline & $\begin{array}{l}\text { Members of rural area } \\
\text { communities }\end{array}$ & 6 & $12 \%$ \\
\hline & Local business & 3 & $6 \%$ \\
\hline \multicolumn{4}{|c|}{ Secondary stakeholder groups } \\
\hline \multirow{6}{*}{$\begin{array}{l}\text { Stakeholders, who } \\
\text { applies problem } \\
\text { solving tools }\end{array}$} & LAG & 51 & $100 \%$ \\
\hline & Business & 16 & $31 \%$ \\
\hline & $\begin{array}{l}\text { Municipality/local } \\
\text { authorities }\end{array}$ & 8 & $16 \%$ \\
\hline & Social partners & 7 & $14 \%$ \\
\hline & $\begin{array}{c}\text { Rural/local government } \\
\text { authorities }\end{array}$ & 3 & $6 \%$ \\
\hline & $\begin{array}{c}\text { Governmental } \\
\text { organizations }\end{array}$ & 2 & $4 \%$ \\
\hline
\end{tabular}

Source: own elaboration 
According to V. Darškuvienė and E. Bendoraitenè (2013), classification of stakeholders is determined by their expectations. The classical Freeman's stakeholder theory indicates that stakeholders are individuals or their groups, which influence or are influenced by organization. And this enables the assumption that different stakeholder groups have different expectations associated with a specific organization. And these particular expectations of stakeholders become their main classification. According to V. Darškuvienè and E. Bendoraitenè (2013), expectations of stakeholders are also interconnected with value creation and expression of social responsibility, by trying to establish the link between their expectations and financial resources of organization and performance.

According to V. Juščius (2009) focusing attention on the roles of primary stakeholder groups and analysis of influence of organizations discloses that they are vitally important for the existence of organizations. This also shows that their values and expectations must be considered first. The list of stakeholders is long and their interests often differ. Therefore it is necessary to coordinate interests of stakeholders by taking their values into account, analysing them through challenges faced and methods for tackling them, and nurtured expectations. Values of stakeholders and organizations are established by negotiation and compromise. When setting their priorities, objectives and tasks rural community-based organizations refer to an established hierarchy of values. Missions and visions of organizations in particular are employed for disclosing main problems, as well as values, in seeking methods and measures for resolving key problems.

According to M. Arimavičiūte (Arimavičiūtè, 2007, pp. 9-17), it is vital to take into account contributions of stakeholders in respect of a specific organization, i.e. that not only organization itself creates value for certain individuals, but also it is possible to establish such relations of stakeholders and organization that stakeholders become useful to organization, and thus considerably contribute to value creation.

Stakeholders of partnership organizational mechanism of rural areas development consist of the various rural organizations, individuals or groups working in partnership with other stakeholders and pursuing rural socio-cultural system objectives. Their interests are closely related to the objectives of rural organizations. The research allowed to set stakeholders of partnership organizational mechanism of rural areas development, which are provided in missions of 51 Lithuanian rural local action groups for the period from 2007 to 2013 (Table 4). In order to clarify needs of stakeholders manifest categories have been identified by "keywords" using the Content method of analysis. Following identification of 17 categories of needs they have been divided into subcategories. Categories and subcategories have been construed and substantiated with evidence derived from the text. Missions have been analysed treating them as a current state of LAG and current LAG situation. 


\section{Conclusions}

1. Rural development complexity is determined by such factors as various stakeholders (local people, local authorities, local action groups, private businesses, various associations, rural users and others) impact for decisions and actions, different motivation, needs and interests in the different levels (local, regional, national) of government. Impact for rural development complexity is made by reasons like increasing involvement of population manifesting through desire to participate in decision making processes and local projects, through different lobby groups, various formal and informal associations, etc.

2. Organizational mechanism is defined as simultaneous operation of organizational process elements (and their links), connected to each other, their interactions, comprising a group of interested individual and collective decisions and actions that lead to behavioral interactions and help to sustainable rural development. Partnership organizational mechanism - totality of information, consultation, engagement and participation decisions, also called nodes and their partnership actions connecting them into chains, while operating synchronously against each other. Thanks to activities of partnership organizational mechanisms (information, consultation, engagement and participation) stakeholders select elements and links of organizational mechanism and thus ensure its functioning. Partnership organizational mechanism is rural development optimization tool. This is a method that can carry out mechanistic function.

3. Rural area development in mechanistic point of view can be expressed as a function that includes organizational mechanism elements (problems, stakeholders, problem-solving tools, results) and the process itself - work of external forces (decision makers, stakeholders), input, intermediate (driving force) and output (driving power) links, which helps to cause movement. Local action group targeting mechanism is synchronous mode of system elements for achieving the purpose.

4. Stakeholders of partnership organizational mechanism in Lithuania's rural areas development consist of the various rural organizations, individuals or groups working in partnership with other stakeholders and pursuing rural socio-cultural system objectives. Their interests are closely related to the organization's well-being. The main driving force of the stakeholders actions, that contribute to realize their interests maximally. 


\section{BIBLIOGRAPHY}

[1] Aligica P. D., 2006, Institutional and stakeholder mapping: frameworks for policy analysis and institutional change, Public organizational review, Vol. 6 (1).

[2] Arimavičıūtė M., 2007, Savivaldos instituciju strateginés analizés metodiniai aspektai, Viešoji politika ir administravimas, Nr. 22, p. 9-17.

[3] Bebbington A., Batterbury S.P.J., 2001, Transnational livelihoods and landscapes: political ecologies of globalization, Ecumene 8, 369-80.

[4] Bechtel W., Abrahamsen A., 2005, Explanation: A mechanist alternative, Studies in history and philosophy of biological and biomedical sciences, Vol. 36.

[5] Bhaskar R., 1978, A realist theory of science, 2nd ed. Harvester, Hassocks.

[6] Bower G. H., 1975, Cognitive Psychology: An Introduction, [in:] W. K. Estes (ed.), Handbook of Learning and cognitive process, New York: Wiley.

[7] BUERET J., 2006, BIODIVERSITY and STAKEHOLDERS: CONCERTATION ITINERARIES, UNESCO.

[8] Coleman J. S., 1994, Foundations of social theory, 1st ed. London: Harvard University Press.

[9] CORK DECLARATION: A LIVING COUNTRYSIDE, 1996, Cork, Ireland, 7-9 November.

[10] CORK DECLARATION: A BETTER LIFE IN RURAL AREAS, 2016, Cork, Ireland, 5-6 September.

[11] Davis G. F., Mcadam D., Scott W. R., Zald M. N. (Eds.), 2005, Social Movements and Organization Theory, New York: Cambridge University Press.

[12] Dalal-Clayton B., Bass S., 2012, Sustainable development strategies - a resource book, 3rd ed. London: Routledge.

[13] Darkoh M.B.K., MваIwa J.E., 2002, Globalization and the livestock industry in Botswana, Singapore Journal of Tropical Geography 23, 149-66.

[14] DaršKuvienĖ V., BendoraitenĖs E., 2013, The Stakeholder Concept Analysis, Organizacijų vadyba: sisteminiai tyrimai, Nr. 68.

[15] Elster J., 1989, Nuts and bolts for the social sciences, Cambridge University Press.

[16] Epp R., Whitson D., 2001, Writing off the rural West: globalization, governments and the transformation of rural communities, Edmonton: University of Alberta Press.

[17] Freeman E. R., 2010, Strategic management: a stakeholder approach, 2nd ed., Cambridge University Press.

[18] Glennan S., 2005, Modeling mechanisms, Studies in history and philosophy of science part C: studies in history and philosophy of biological and biomedical sciences, Vol. 36.2.

[19] Gray I., Lawrence G., 2001, A future for regional Australia, Cambridge: Cambridge University Press.

[20] Harre R., 1985, The philosophies of science, 2nd ed. Oxford University Press.

[21] HÉDoin C., 2013, Modeling Social Mechanisms: Mechanism-Based Explanations and Agent-Based Modeling in the Social Sciences, University of Reims Champagne-Ardenne, France.

[22] Hedstrom P., Swedberg R., 1998, Social Mechanisms. An analytical Approach to Social Theory, Cambridge University Press, United Kingdom.

[23] Hernes G., 1998, Real virtuality, [in:] P. Hedström and R. Swedberg (eds.), Social mechanisms: An analytical approach to social theory, Cambridge, UK: Cambridge University Press.

[24] Hooghe L., Marks G., 2001, Multi-level Governance and European Integration, Lanham: Rowman and Littlefield. 
[25] Hurwicz L., 1973, The Design of Mechanisms for Resource Allocation, American Economic Review. Papers and Proceedings, Vol. 63.

[26] Hurwicz L., Stanley R., 2007, Designing Economic Mechanisms, Cambridge: Cambridge University Press.

[27] JuščIus V., 2009, Imoniu socialinè atsakomybe ir organizacijų tapatumas šiuolaikinès ekonominès krizes kontekste, Ekonomika ir vadyba, 2009 (14).

[28] Killick T., 2001, Globalization and the rural poor, Development Policy Review 19.

[29] Kooiman J., 2000, Societal governance: levels, modes, and orders of social political interaction, [in:] Pierre J. (ed.), Debating Governance. Authority, steering and democracy, Oxford: Oxford University Press.

[30] Krone K. J., Jablin F. M., Putnam L. L., 1987, Communication theory and organizational communication: Multiple perspectives, Handbook of organizational communication: An interdisciplinary perspective, Vol. 18.1.

[31] Little D., 1991, Varieties of social explanation: An introduction to the philosophy of social sciences, CO: Westview Press, Boulder.

[32] LoWE P., WARD N., 2007, Sustainable rural economies: some lessons from the English experience, p. 15 , vol. 5 .

[33] LuKESCH R., 2007, The LAG handbook - a guide through the stunning word of local action groups, LEADER+.

[34] Lunenburg Fred C., 2012, Organizational Structure: Mintzberg's Framework, International Journal of Scholarly, Academic, Intellectual Diversity, Volume 14, No. 1.

[35] Machamer P., Darden L., Craver C. F., 2000, Thinking about Mechanisms, Philosophy of Science, Vol. 67 (1).

[36] Milkowski M., 2011, Beyond Formal Structure: A Mechanistic Perspective on Computation and Implementation, Journal of Cognitive Science, Vol. 12.

[37] Naujokaitis S., 1990, Mechanizmu ir mašinų teorija, Vilnius: Mokslas.

[38] Osborne S. P., 2006, The New Public Governance?, Public Mangement Review, Vol. 8, Issue 3.

[39] Ostrom E., 2000, Collective action and the evolution of the social norms, Journal of economic perspectives, Vol. 14 (3).

[40] Ostrom E., 2005, Understanding institutional diversity, Princeton University Press.

[41] Pasquier M., Villeneuve J., P., 2007, Organizational barriers to transparency: a typology and analysis of organizational behavior tending to prevent or restrict access to information, International Review of Administrative Sciences, March 2007 (73).

[42] Pajunen K., 2008, The Nature of Organizational Mechanisms, Organization Studies, Vol. 29 (11).

[43] Pérez Sáinz J.P., Andrade-Eekhoff K.E, 2003, Communities in globalization: the invisible Mayan Nahual, Lanham, MD: Rowman and Littlefield.

[44] Powell W., 1991, Neither Market nor Hierarchy: Network Forms of Organisation, [in:] Thompson G., Frances J., Levavcic R. and Mitchell J. (eds), Markets and Hierarchies and Networks: The Co-ordination of Social Life, London: Sage.

[45] Pierre J., 2000, Debating Governance. Authority, steering and democracy, Oxford: Oxford University Press.

[46] Raipa A., 2012, Modernus viešasis valdymas, Kaunas: Vitae Litera.

[47] RaIPA A., 2016, Šiuolaikinio viešojo administravimo pagrindai, Registrų Centras, Vilnius.

[48] Reed M., 2000, Organization, trust and control: A realist analysis, Organization Studies, Vol. 22. 
[49] Rey-Valette H., Lardon S., Chia E., 2008, Special issue on Governance: Institutional and Learning Plans facilitating the Appropriation of Sustainable Development, International Journal of Sustainable Development, Vol. 11, No. 2-3-4.

[50] Ryвакоvas E., 2009, A novel approach of the driving forces of socio-economic regional development, Socialiniai mokslai, Vol. 1 (63).

[51] Schumpeter J. A., 1963, History of Economic Analysis, New York: George Allen.

[52] Schelling T., 1998, Social mechanisms and social dynamics, [in:] Social mechanisms: An analytical approach to social theory, Cambridge University Press.

[53] Sindhav B., Adidam P. T., 2005, Marketing Communication as Organizational Communication: Exploration and Synthesis of the Underlying Theoretical Perspectives, Innovative Marketing, Vol. 1 (2).

[54] Stinchсомве A. L., 1991, The conditions of fruitfulness of theorizing about mechanisms in social science, Philosophy of the Social Sciences, Vol. 21.

[55] Stoll-Kleemann S., Welp M., 2006, Towards a more effective and democratic natural resources management, Stakeholder dialogues in natural resources management: theory and practice, Berlin - Heidelberg: Springer Verlag.

[56] Šimanskiené L., TARASevičıus T., 2010, Organizacinès kultūros ir vadovu tipu sąajos, Management theory and studies for rural business and infrastructure development, Vol. 20 (1).

[57] Torre A., Zuindeau B., 2009, Proximity economics and environment: assessment and prospects, Journal of Environmental Planning and Management, Vol. 52, No. 1.

[58] Welch R., 2002, Legitimacy of rural local government in the new governance environment, Journal of rural studies, 18 .

[59] Wettenhall R., 2003, The rhetoric and reality of public-private partnerships, Public Organization Review, 3, 1 .

[60] Woods M., 2007, Engaging the global countryside: globalization, hybridity and the reconstitution of rural place, Progress in Human Geography, 31(4).

[61] Yescombe C., 2007, Public-Private Partnerships: Principles of Policy and Finance, London: Butterworth-Heinemann/Elsevier.

[62] Zakarevičıus P., 2010, Organizacijos veiklos procesų valdymas, Organizacijų vadyba: sisteminiai tyrimai, Vol. 56.

\section{ELECTRONIC SOURCES}

[63] Campbell J. L., 2002, Where do we stand? Common mechanisms in organizations and social movements research, http://webuser.bus.umich.edu/Organizations/smo/protected/resources/2002/ wherestand.pdf, (08.04.2016).

[64] Freeman E. R., 2001, Stakeholder Theory of the Modern Corporation, Perspectives in Business Ethics Sie, https://businessethics.qwriting.qc.cuny.edu/files/2012/01/Freeman.pdf (08.04.2016).

[65] Hurwicz L., 2009, Asimetrine informacija ir ekonomines institucijos, Nobelio $2007 \mathrm{~m}$. Ekonomikos mokslų premijos laureatai, Pinigu studijos, No. 2, pp. 70-94, https://www.lb.lt/nobelio_laureatai_7 (08.10.2016).

[66] PARTNERSHIPS: FRAMEWORKS FOR WORKING TOGETHER. STRENGTHENING NONPROFITS: A CAPACITY BUILDER'S RESOURCE LIBRARY (2010), http://www.strengtheningnonprofits.org/resources/guidebooks/Partnerships.pdf (10.10.2016).

[67] Phills J.A., Deiglmeier K. \& Miller D.T., 2008, Rediscovering Social Innovation, Stanford Social Innovation Review, Fall, pp. 34-43, http://csi.gsb.stanford.edu/print/2307 (08.04.2016). 